Sharkhun S. V. ${ }^{1}$, Sirina N. F. ${ }^{2}$

${ }^{1}$ Ural Institute of State Fire Service of EMERCOM of Russia,

${ }^{2}$ Ural State University of Railway Transport,

Yekaterinburg, Russia

E-mail: ${ }^{1}$ S_sharhun@mail.ru,2NSirina@usurt.ru

\title{
RESULTS PRACTICAL APPLICATION OF THE DUPLICATING WAY WSEM-PC FOR THE NOTIFICATION OF PEOPLE AT FIRE IN OFFICE BUILDINGS OF JSC "RUSSIAN RAILWAYS"
}

\begin{abstract}
The results of the natural observation of evacuation of office buildings workers of JSC "Russian Railways” with application of various notification ways are presented in the article and the time of their response to a signal is defined. Confidential level of the possibility of use of the considered mathematical laws of distribution for the time of response description of the "Fire" signal depending on the notification way is determined. Based on the chosen law of distribution comparative assessment of efficiency of the notification at the fire depending on a notification way in comparison with standard values, and also the existing traditional ways of the notification has been conducted. The data analysis and check of the possibility of the application of the considered laws of distribution to the results of the pilot study allows to make a conclusion that for the description of time to make a decision begin evacuation it is possible to use the exponential law of distribution.
\end{abstract}

Keywords: the warning system of people at fire, the notification duplicating way, the distribution law, natural observation, evacuation time.

\section{Шархун С. В. ${ }^{1}$, Сирина Н. Ф. ${ }^{2}$}

${ }^{1}$ Уральский институт Государственной противопожарной службы МЧС России,

2 Уральский государственный университет путей сообщения,

Екатеринбург, Россия

E-mail: ${ }^{1} S \_s h a r h u n @ m a i l . r u,{ }^{2} N$ Sirina@usurt.ru

\section{РЕЗУЛЬТАТЫ ПРАКТИЧЕСКОГО ПРИМЕНЕНИЯ ДУБЛИРУЮЩЕГО СПОСОБА СОУЭ-ПК ДЛЯ ОПОВЕЩЕНИЯ ЛЮДЕЙ ПРИ ПОЖАРЕ В АДМИНИСТРАТИВНЫХ ЗДАНИЯХ ОАО «РОССИЙСКИЕ ЖЕЛЕЗНЫЕ ДОРОГИ»}

\begin{abstract}
Аннотация. В статье представлены результаты натурного наблюдения за эвакуацией работников административных зданий ОАО «РЖД» с применением различных способов оповещения, и определено время их реагирования на сигнал. Определен доверительный уровень возможности использования рассмотренных математических законов распределения для описания времени реагирования на сигнал «Пожар» в зависимости от способа оповещения. На основании выбранного закона распределения была выполнена сравнительная оценка эффективности оповещения при пожаре в зависимости от способа оповещения в сравнении с нормативными значениями, а также существующими традиционными способами оповещения. Анализ данных и проверка возможности применения рассмотренных законов распределения по результатам пилотного исследования позволяют сделать вывод о том, что для описания времени принятия решения о начале эвакуации можно использовать экспоненциальный закон распределения.
\end{abstract}

Ключевые слова: система оповещения людей при пожаре, дублирующий способ оповещения, закон распределения, натурное наблюдение, время эвакуации.

(C) Sharkhun S. V., Sirina N. F., 2017

\section{Introduction}

Nowadays the main systems promoting safety of people at fire in office buildings are the automatic fire alarm system (AFAS) and the warning system and managements of people at fire (WSEM) evacuation. The main objective of this system is the operational notification of the people who are in the building and management of process of their evacuation to a safe zone $[1,2]$.

As it is noted in [2], the evacuation process of people at fire can conditionally be divided into three main stages (Fig. 1): lag effect of the FPÖ systems, time of making decision on the beginning of evacuation, the real movement time on the evacuation ways. It is also fair for the office buildings included into the JSC "Russian Railways" control system.

The time spent for fire detection (a lag effect of systems of the AFAS) can take several tens of seconds and depends on a technical component of the AFAS system - correctness of installation, timeliness of maintenance and scheduled preventive maintenance. It is impossible to reduce this time interval to zero. However at today there are ways of decreasing the time of making decision of the evacuation beginning. 


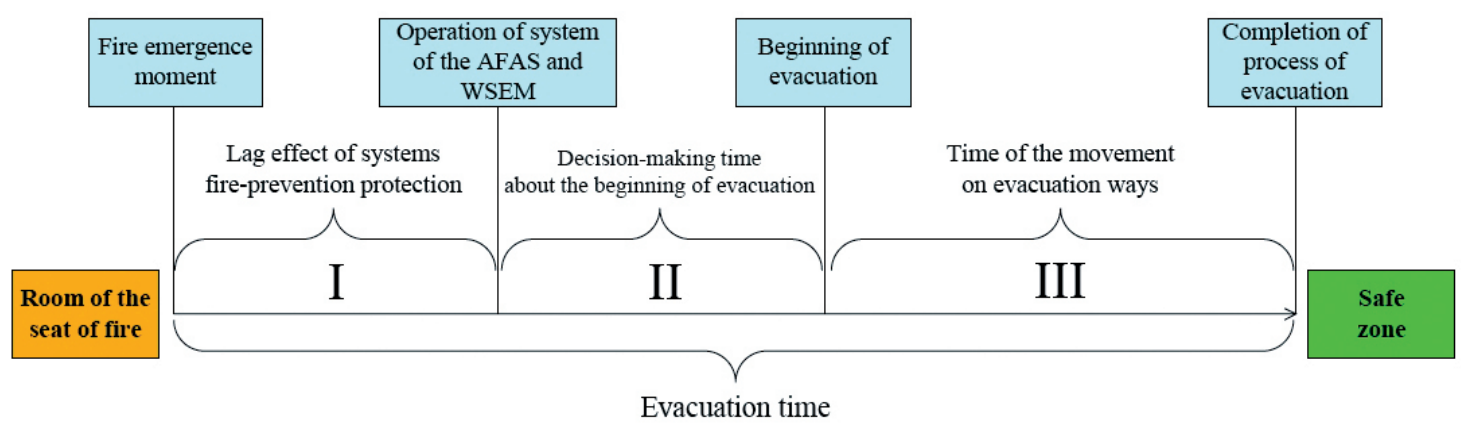

Fig. 1. Actual time of evacuation

\section{Prerequisites and means for a solution}

Reduction of a time interval on making decision on the beginning of evacuation at the moment is an urgent task for the majority of buildings with a big congestion of people and the JSC "Russian Railways" objects are not exceptions. For the solution of this task in modern conditions it is possible to allocate two directions (Fig. 2) - training of workers and personnel of the organizations in actions at receipt of a signal of the fire for the purpose of a conditioned reflex development: "alarm - immediate evacuation"; the use of special technical means aimed to persuade a person to make the right decision when his health and life are threatened due to the fire impacts.

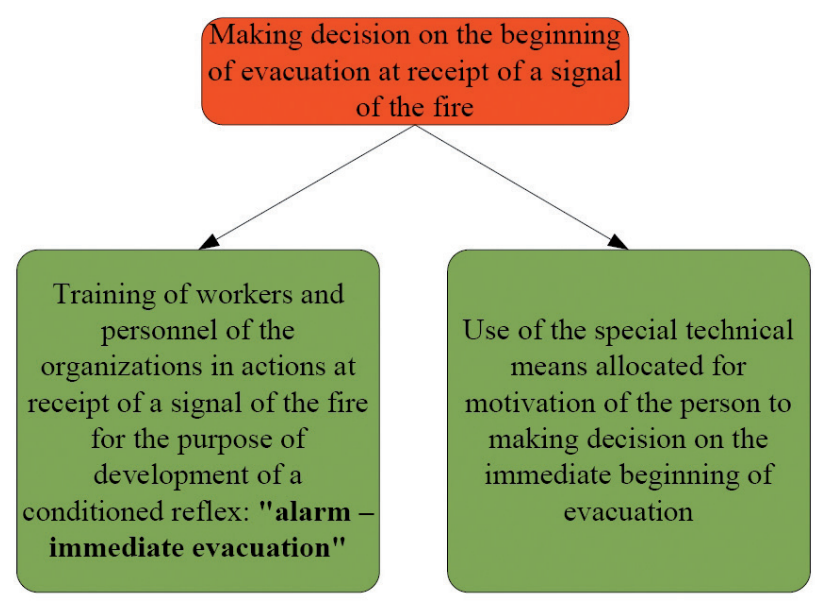

Fig. 2. Possible ways of time reduction of the evacuation beginning

The works on the first direction are being conducted for quite a long time - the requirements on the necessity of the evacuation plans working off and the conducting exercises for people at fire evacuation has existed for more than 10 years. However, the practice shows, when carrying out the announced doctrines in advance people act quickly and correctly, and hearing the same signal in other times people act differently - they try to establish the signal reliability, to find out what really happened, if the signal is to him personally or not, and in some cases a person just continues to perform his work.

Today great attention is paid to the creation of any technical system aimed to force a person to certain actions when receiving "Fire". It is done for the people to be able to evacuate from the building and as therefore save the people's health and life.

\section{The solution of the considered problem}

One of the funds allocated for the persons motivation to making decisions on the immediate beginning of evacuation is the duplication of people's warning about the fire of WSEM-PK [3]. It is based on the use of a technical component which allows to adjust interrelation between the WSEM system and the local computer network ( $\mathrm{LCN})$ which is available at the enterprise for the purpose of duplication of a fire signal on all personal computers connected to a LAN of the office building.

The essence of the applied duplicating way is that in office buildings the installation of the special software WSEM-PC is installed in the server computer. It allows, when receiving the fire signal from the reception and the control device of the fire alarm system on the communication line means, to carry out this fire signal duplication on all personal computers (PC) connected to a LAN. At the same time there are messages in the personal computer screen on the fire and the scheme of evacuation from the room with the definite personal computer indicating the nearest emergency exit. The personal computer blocking is conducted to avoid its further work. Except for a visual signal to increase the efficiency of the warning in the program complex WSEMPC the alarm voice of the displayed information is provided, on means of the previously recorded voice warning. For example: "Attention! The building's on fire! All Personnel proceed to the emergency exit immediately!”.

This way is described in works in detail [1]. Its application is possible in office buildings of JSC "Russian Railways" without essential material inputs and doesn't contradict the existing normative documents as its introduction is carried out in the existing WSEM and LAN system. 


\section{Results and discussion}

For the analysis of the efficiency of the offered duplicating notification way there are natural observations of people's behavior when receiving a "Fire" signal are conducted. Observations were made in five various office buildings of JSC "Russian Railways" (further - the Building no. 1, no. 2, ...no. 5). In different days, approximately in identical time during the working day the signal of the fire was given; the notification was carried out by the 4 options:

- the standard warning system and managements of evacuation of people at fire (WSEM);

- standard WSEM + the duplicating notification way WSEM-PC (only sound component);

- standard WSEM + the duplicating notification way WSEM-PC (a sound component and the visual notification);

- standard WSEM + the duplicating notification way WSEM-PC (a sound component, the visual notification and blocking of the personal computer).

During the observation the response time to the fire signal, that is, the period from the signal receiving till making the decision to the evacuation beginning by each person. The received temporary indicators were included into the protocol. The generalized results of the observation are given in Table 1.

Table 1

The generalized results of natural observation of people's behavior, when receiving a signal of the fire, at various notification ways

\begin{tabular}{|c|c|c|c|c|}
\hline $\begin{array}{c}\text { Experi- } \\
\text { ment } \\
\text { No. }\end{array}$ & $\begin{array}{c}\text { Name of the } \\
\text { building }\end{array}$ & $\begin{array}{l}\text { Way notifica- } \\
\text { tion of people }\end{array}$ & $\begin{array}{l}\text { Number } \\
\text { of people }\end{array}$ & $\begin{array}{l}\text { As much } \\
\text { as possible } \\
\text { time of } \\
\text { response } \\
\text { to a signal, } \\
\text { min }\end{array}$ \\
\hline 1 & Building no. 1 & \multirow{5}{*}{$\begin{array}{l}\text { standard } \\
\text { WSEM }\end{array}$} & 153 & 1.94 \\
\hline 2 & Building no. 2 & & 174 & 2.05 \\
\hline 3 & Building no. 3 & & 162 & 1.98 \\
\hline 4 & Building no. 4 & & 158 & 2.16 \\
\hline 5 & Building no. 5 & & 147 & 2.05 \\
\hline 6 & Building no. 1 & \multirow{5}{*}{$\begin{array}{c}\text { standard } \\
\text { WSEM + } \\
\text { WSEM-PC } \\
\text { (only sound } \\
\text { component }\end{array}$} & 158 & 1.70 \\
\hline 7 & Building no. 2 & & 171 & 1.72 \\
\hline 8 & Building no. 3 & & 155 & 1.81 \\
\hline 9 & Building no. 4 & & 158 & 2.01 \\
\hline 10 & Building no. 5 & & 143 & 1.95 \\
\hline 11 & \begin{tabular}{|l|} 
Building no. 1 \\
\end{tabular} & \multirow{5}{*}{\begin{tabular}{|c|} 
standard \\
WSEM + \\
WSEM-PC \\
(a sound \\
component \\
and the visual \\
notification)
\end{tabular}} & 163 & 1.65 \\
\hline 12 & Building no. 2 & & 174 & 1.50 \\
\hline 13 & Building no. 3 & & 163 & 1.58 \\
\hline 14 & Building no. 4 & & 136 & 1.91 \\
\hline 15 & Building no. 5 & & 149 & 1.84 \\
\hline
\end{tabular}

\begin{tabular}{|c|c|c|c|c|}
\hline $\begin{array}{c}\text { Experi- } \\
\text { ment } \\
\text { No. }\end{array}$ & $\begin{array}{l}\text { Name of the } \\
\text { building }\end{array}$ & $\begin{array}{l}\text { Way notifica- } \\
\text { tion of people }\end{array}$ & $\begin{array}{l}\text { Number } \\
\text { of people }\end{array}$ & $\begin{array}{c}\text { As much } \\
\text { as possible } \\
\text { time of } \\
\text { response } \\
\text { to a signal, } \\
\text { min }\end{array}$ \\
\hline 16 & Building no. 1 & \multirow{5}{*}{\begin{tabular}{|c} 
standard \\
WSEM + \\
WSEM-PC \\
(a sound \\
component, \\
the visual no- \\
tification and \\
blocking of \\
the personal \\
computer)
\end{tabular}} & 151 & 1.57 \\
\hline 17 & Building no. 2 & & 172 & 1.41 \\
\hline 18 & Building no. 3 & & 159 & 1.51 \\
\hline 19 & Building no. 4 & & 147 & 1.83 \\
\hline 20 & Building no. 5 & & 142 & 1.72 \\
\hline
\end{tabular}

The data obtained as a result of natural observation have been processed by means of the statistical graphic STATGRAPHICS for Windows [4] system during which the minimum, maximum and average time of response to a signal, and also an average square deviation were defined.

According to the obtained data graphic dependence (Fig. 3) of dynamics of average time of response to the "Fire" signal in the examined buildings depending on the notification way from which it is obvious (on the example of the Building no. 1) that the average time of people's reaction if only a standard way of notification is used is $18.96 \mathrm{sec}$. The average reaction time at partial use (only sound notification) of an additional notification way about the fire (WSEM-PC) is 16.33 which is $13.90 \%$ less. The average time of reaction when using the sound and visual notification (WSEM-PC) is 13.60 which is $28.29 \%$ less. And the average time of an additional notification way about the fire (WSEM-PC) is 8.97 which is $52.70 \%$ less than initial.

When the obtained data research the determination of the confidential level of the possibility of the use of various mathematical laws for the description of the dynamics of the response time to the "Fire" signal was the main objective.

So for the choice of the mathematical law of distribution and the description of time of response to the fire signal, the following distribution laws have been analyzed:

- normal law;

- logarithmic normal law;

- gamma distribution;

- exponential law;

- Weibull's distribution [5].

\section{Conclusion}

From the analyzed five distributions the possibility of the normal law application has been rejected, other considered laws can be used for the modeled event description "has heard - has made the decision - has begun the movement" [5].

The obtained data by the results of the mathematical research on the confidential level of various distribution laws use are provided in Table 2. 


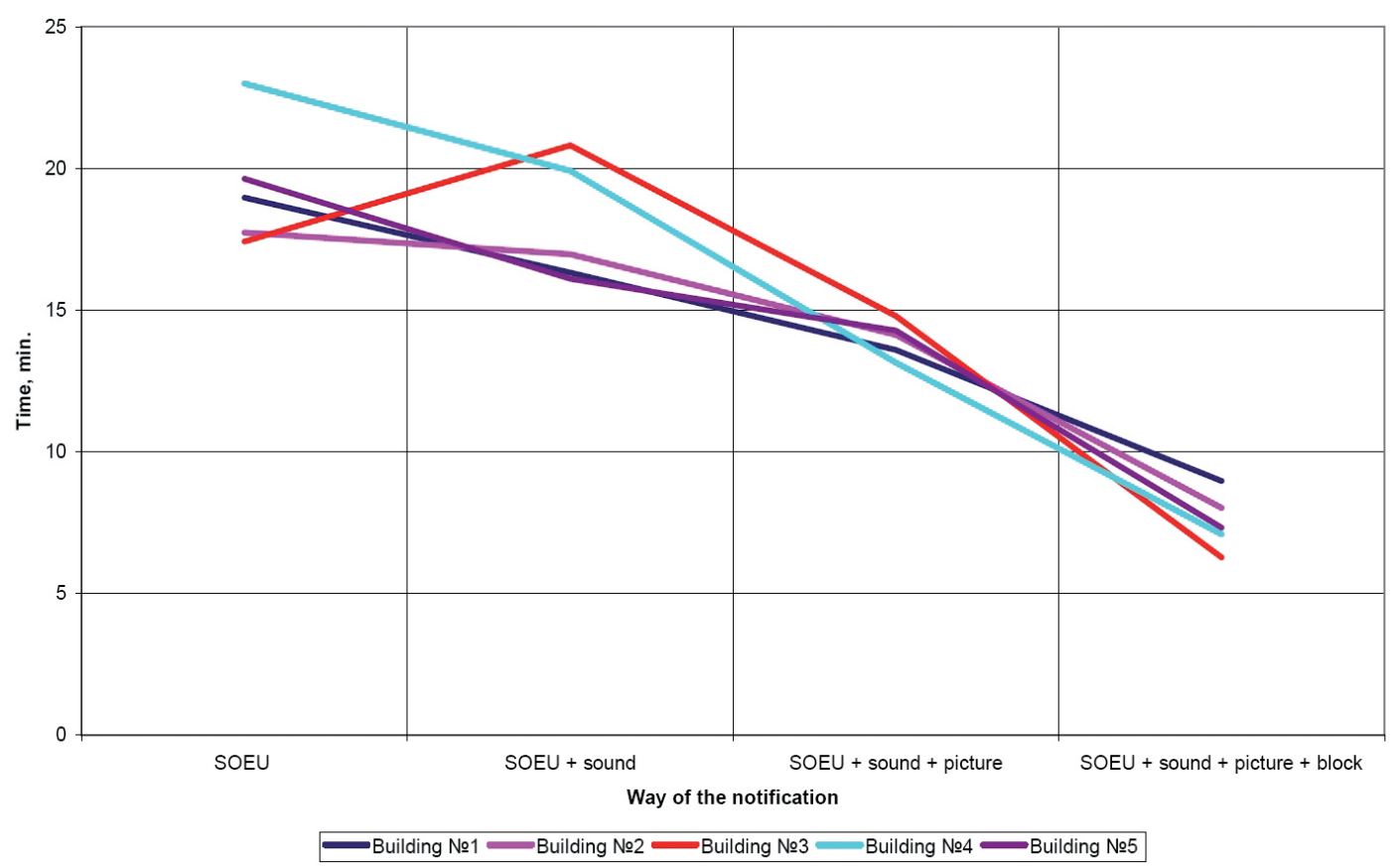

Fig. 3 Dynamics of the average time of response to the "Fire" signal depending on the notification way

Therefore, application of WSEM-PC will allow

Table 2 to increase the number of the ones to react to $0.5 \mathrm{~min}$

Confidential level of a possibility of mathematical laws use for the obtained data research

\begin{tabular}{|c|c|c|c|c|c|}
\hline $\begin{array}{l}\text { Law of distri- } \\
\text { bution }\end{array}$ & 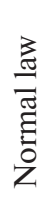 & 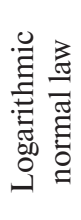 & 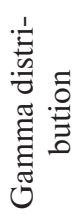 & 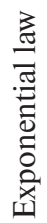 & 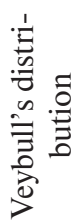 \\
\hline $\begin{array}{l}\text { Confidential } \\
\text { level of use, \% }\end{array}$ & 10 & 93 & 90 & 95 & 90 \\
\hline
\end{tabular}

The data analysis and check of the possibility of the application of the considered laws of distribution to the results of the pilot study (criterion a chi-square, Kolmogorov-Smirnov's criterion, $[6,7,8]$ ) allows to make a conclusion that for the description of time to make a decision begin evacuation it is possible to use the exponential law of distribution with the confidential level of $95 \%(p=0.95)$.

On the basis of the used mathematical model a comparative evaluation of the fire notification efficiency depending on the notification way in comparison with standard values, as well as the existing traditional notification ways was conducted. As the result the following forecasts were received: by the time of $t=$ $=0.5 \mathrm{~min}$. the response to the standard WSEM is $43.77 \%$, on WSEM + a sound - $49.93 \%$, on WSEM + the picture on the PC monitors + a sound in speakers $-56.44 \%$ and for WSEM+ the picture on the PC monitors + a sound in speakers + compulsory personal computer block $63.16 \%$. Graphically the data are submitted in Fig. 4. time point for $19.39 \%$

By the time of $t=1.0 \mathrm{~min}$ the response to the standard WSEM will be $68.38 \%$, on WSEM + a sound $-74.93 \%$, on WSEM + the picture on the PC monitors + a sound in speakers $-81.09 \%$ and for WSEM + the picture on the $\mathrm{PC}+$ monitors a sound in speakers + compulsory personal computer block $-86.43 \%$. Graphically the data are submitted in Fig. 5.

Therefore, the number of the ones to react in $1.0 \mathrm{~min}$ time point for $18.05 \%$ will allow to increase applications of WSEM-PC.

By the time of $1.5 \mathrm{~min}$ the response to standard WSEM will be $82.22 \%$, on WSEM+ a sound $-87.44 \%$, on WSEM + the picture on the PC monitors + a sound in speakers $-91.74 \%$ and for WSEM + the picture on the PC monitors + a sound in speakers + compulsory personal computer block $-95.00 \%$. Graphically the data are submitted in Fig. 6.

Therefore, the number of the ones to react in $1.5 \mathrm{~min}$ time point for $12.78 \%$ will allow to increase applications of WSEM-PC.

Figs. 4-6 show that the suggested notification way WSEM-PC makes the greatest impact at the initial stages of people's notification about the fire, just in time of fire when in actual practice people do not completely understand the danger of the emergency situation and do not always take actions, necessary for the evacuation.

Thus, it is possible to make a conclusion that the application of the duplicating notification way WSEMPC "Fire" has a noticeable positive impact on the average time of a signal response. 


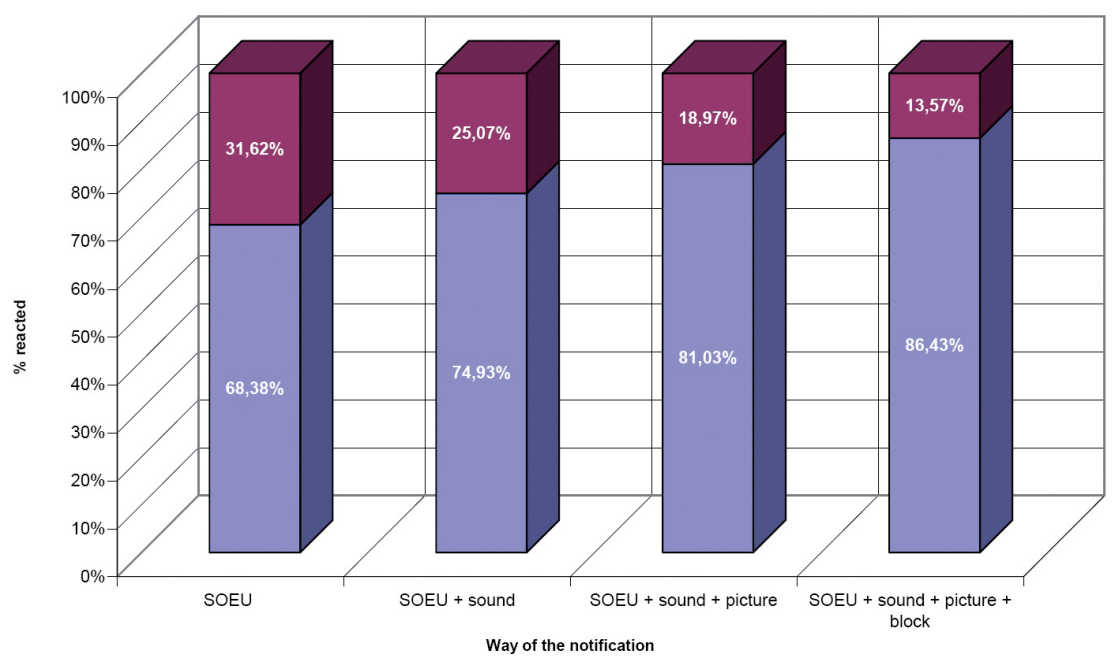

पReacted to a signal $\mathbf{\square}$ Not reacted to a signal

Fig. 4. Quantity of the ones to react to the notification signal in 0.5 min time point

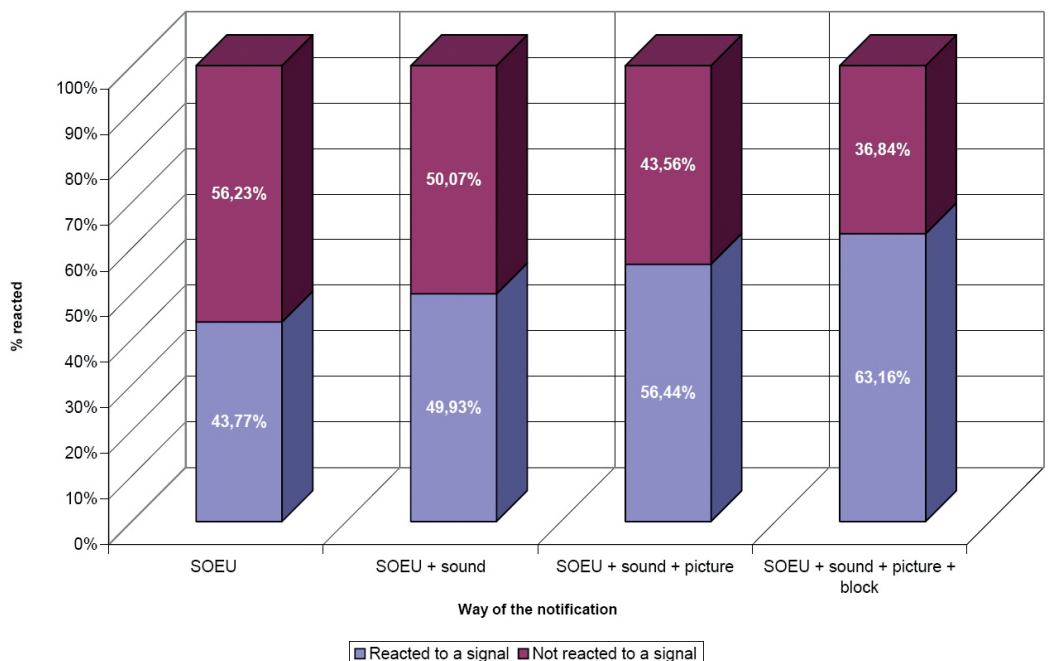

Fig. 5. Quantity of the ones to react to the notification signal in $1.0 \mathrm{~min}$ time point

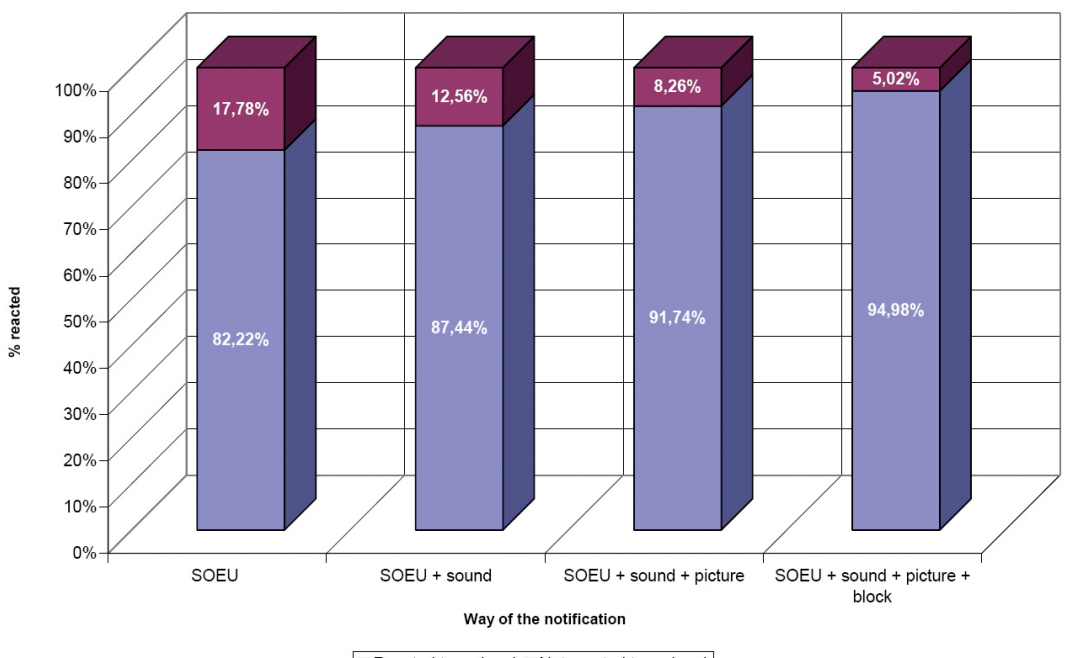

$\square$ Reacted to a signal $\square$ Not reacted to a signal

Fig. 6. Quantity of the ones to react to the notification signal in 1.5 min time point 


\section{References}

1. Sharkhun S. V., Sirina N. F. Snizhenie vremeni nachala evakuatsii pri pozhare kak osnova obespecheniia bezopasnosti rabotnikov administrativnykh zdanii OAO "RZhD" [Reducing the time for the beginning of evacuation in case of fire as a basis for ensuring the safety of employees of the administrative buildings of Russian Railways]. Transport Urala - Transport of the Urals, 2016, no. 2 (49), pp. 34-38. (In Russ.).

2. Sharkhun S. V., Briukhov E. N. Svoevremennoe nachalo evakuatsii pri pozhare kak osnova ee effektivnosti [Timely initiation of evacuation in case of fire as a basis for its effectiveness]. Bezopasnost'zhiznedeiatel'nosti - Life Safety, 2015, no. 5, pp. 54-57. (In Russ).

3. Sharkhun S.V. Sistema opoveshcheniia $i$ upravleniia evakuatsiei liudei pri pozhare - SOUE-PK [The system of warning and control of the evacuation of people in case of fire - WSEM-PC]. Unified Register of Russian Programs for Electronic Computers and Databases, application no. 2012615195, certificate no. 2012617518, 20.08.2012.

4. Diuk V.A. Obrabotka dannykh na PK v primerakh [Data processing on personal computers in the examples]. Saint Petersburg, Piter Publ., 1997. 240 p. (In Russ.).
5. Sharkhun S. V., Sirina N.F., Shterenzon V.A. Analiz effektivnosti integratsii dubliruiushchego sposoba opoveshcheniia v sistemu upravleniia infrastrukturoi zheleznodorozhnogo transporta na primere zdanii OAO "RZhD" [Analysis of the effectiveness of integration of a duplicate method of notification in the infrastructure management system of railway transport by the example of the building of the Sverdlovsk Railway Administration]. Transport Urala - Transport of the Urals, 2017, no. 1, pp. 19-24. (In Russ.).

6. Khan G., Shapiro S. Statisticheskie modeli v inzhenernykh zadachakh [Statistical models in engineering problems]. Moscow, Mir Publ., 1969. 395 p. (In Russ.).

7. Pereverzev E. S. Sluchainye protsessy v parametricheskikh modeliakh nadezhnosti [Random processes in parametric reliability models]. Kiev, Naukova dumka Publ., 1987. 240 p. (In Russ.).

8. Aivazian S.A., Eniukov I. S., Meshalkin L. D. Prikladnaia statistika: Osnovy modelirovaniia i pervichnaia obrabotka dannykh [Applied Statistics: Basics of Modeling and Primary Data Processing: A Handbook]. Moscow, Finansy i statistika Publ., 1983. 471 p. (In Russ.). 